\title{
A Natural Analogue Study of Radionuclide Migration in a Water Conducting Fracture in Crystalline Rock
}

\author{
By W. R. Alexander ${ }^{1}$, R. D. SCOTT ${ }^{2}$, A. B. MACKENZIE ${ }^{2}$ and I. G. MCKINLEY ${ }^{3}$ \\ 1 Paul Scherrer Institut, 5303 Würenlingen, Switzerland \\ 2Scottish Universities Research and Reactor Centre, Glasgow G75OQU, Scotland \\ 3NAGRA, 5401 Beden, Switzerland
}

(Received September 12, 1987; revised February 18, 1988)

Radionuclide /REE / Hydrothermal alteration /Migration / Redox reactions / Fissures

\section{Summary}

A suite of elements including $U$, Th and the REE are examined in a rock drillcore, from the Böttstein granite of northern Switzerland, which is intersected by a (suspected) water carrying fracture. Examination of the natural decay series indicates a nonfractionated loss of $U$ throughout the core over the last 300000 years or so. There has also been a more recent addition of ${ }^{234} \mathrm{U}$ and ${ }^{230} \mathrm{Th}$ to the rock in the vicinity of the fracture. REE data indicate the importance of previous alteration of the rock for later radionuclide uptake.

\section{Introduction}

This project was initiated by NAGRA (Switzerland) as part of the assessment of the concept of nuclear fuel waste disposal in a deep crystalline rock body. Previous experimental work carried out by NAGRA and SKB (Sweden) suggest that, in the instance of the cumulative failure of near-field barriers in the high-level waste repository, hydraulically connected fractures in the rock body could be very important far-field routes of migration (and possible sites of retardation) of radionuclides dissolved in the groundwaters. As part of this work we have conducted a natural analogue study on a rock drillcore which intersects a suspected water-conducting fracture in granite from the Böttstein area of northern Switzerland. Using disequilibrium in natural decay series radionuclides and the distribution of rare earth elements (REE), we can appraise past elemental migration (or lack of migration) associated with the fracture on a geological time scale. The process involved in the transport of such species out of the bulk rock are analogous to that which could cause retardation of dissolved radionuclides by their transport in to the rock - the socalled "matrix diffusion".

Here we report new data on the rock drillcore, which is considered with previously reported natural decay series results [1] for the same samples. An attempt is made to define more precisely the controls on radionuclide migration and retardation in association with water conducting fractures. Reference is made to the water temperature and redox conditions necessary to induce migration of a suite of elements, including $U, T h$ and the REE which are chemical analogues of the actinides in the $6^{+} / 4^{+}, 4^{+}$ and $3^{+}$oxidation states respectively.

\section{Analytical methods}

Sub-samples from the rock core were crushed and powdered prior to analy sis for natural decay series nuclides by $\alpha$-spectrometry and for a range of stable elements by instrumental neutron activation analysis (INAA) as described below.

For $\mathrm{U}$ and Th measurements, samples of the powdered material were spiked with ${ }^{232} \mathrm{U}$ in equilibrium with ${ }^{228} \mathrm{Th}$ as a yield tracer and then digested with aqua regia and $\mathrm{HF}$ in a vented microwave oven $[2,3\}$. Insoluble material was further digested in the microwave oven in a Parr microwave transparent, high-pressure digestion bomb. Once the samples were completely dissolved in $9 \mathrm{M} \mathrm{HCl}, \mathrm{U}$ and Th were recovered from the solution by radiochemical separations based on a previously reported method [4] and were then electrodeposited onto stainless-steel planchettes for $\alpha$-particle detection by silicon surface barrier detectors. In the Th analysis, it is important to note that both spike and sample contain ${ }^{228} \mathrm{Th}$ and that it is corrected for on the assumption that the ${ }^{228} \mathrm{Th}$ in the sample is in secular equilibrium with the ${ }^{232} \mathrm{Th}$. This assumption was checked on several unspiked samples and was found to be valid.

${ }^{226} \mathrm{Ra}$ analyses were carried out by direct counting of the $609 \mathrm{KeV}$ peak in the $\gamma$ - spectrum of the ${ }^{226} \mathrm{Ra}$ decay products in a $4 \mathrm{~g}$ sub-sample of the untreated, powdered granite. It should be stressed that using this peak, produced by ${ }^{214} \mathrm{Bi}$ decay, assumes no significant loss of ${ }^{22} \mathrm{R} n$ from the sample. The precision of the results is better than $\pm 4 \%$ for the ${ }^{234} \mathrm{U} /{ }^{238} \mathrm{U}$ activity ratios, better than $\pm 7 \%$ for the ${ }^{230} \mathrm{Th} /{ }^{234} \mathrm{U}$ activity ratios and $\pm 15 \%$ for the ${ }^{226} \mathrm{Ra} /{ }^{230} \mathrm{Th}$ activity ratios.

INAA was carried out on $0.2 \mathrm{~g}$ of untreated powdered rock using published techniques $[5,6]$. The samples were irradiated in a thermal neutron flux of $3 \times 10^{12}$ neutron $\mathrm{cm}^{-2} \mathrm{~s}^{-1}$ after which a series of $\gamma$-spectroscopy measurements were performed with co-axial $\mathrm{Ge}(\mathrm{Li})$ detectors and a planar $\mathrm{Ge}(\mathrm{Li})$ detector. Gamma spectra were recorded on a EG + G. Ortec 7032 analyser and were analysed by the Ortec peak search programma GAMMA 2. INAA calculations were performed by the SURRC programme NAA [7].

\subsection{Sample description}

The drillcore described here is from the Böttstein area of northern Switzer land, some $30 \mathrm{~km}$ north-west of Zürich. The geology and geochemistry of the Böttstein granite complex is described in two NAGRA reports $[8,9]$ and this particular section of drillcore (BOE 618.34-618.70 m) is described in detail elsewhere [1].

In summary, rock core BOE is a coarsed-grained, biotite rich porphyritic granite with $\mathrm{K}$-feldspar phenocrysts. There is a contact between the granite and a pegmatite with the (suspected) water carrying fracture occuring in the pegmatite only a few centimetres from the contact. Major constituents of the granite are K-feldspar, quartz, plagioclase and biotite with accessory apatite and zircon. Some late magmatic muscovite has formed from the breakdown of K-feldspar and biotite and pseudomorphs of pinite after cordierite are common. The pegmatite is coarsegrained with quartz, K-feldspar and albite with accessory muscovite and tourmaline. The fracture filling consists of calcite, quartz, clays (illite and smectite) and apatite.

\section{Results}

Although the fracture lies in the middle of a pegmatite vein in the granite, the rock on only one side of the fracture has been examined for indications of migration.

The distribution of $\mathrm{U}$ and its daughter decay products throughout the rock drillcore are displayed in Figure 1 and listed in Table 1 and the levels of $\mathrm{Fe}, \mathrm{Mn}, \mathrm{Co}, \mathrm{Cs}$ and the REE's La, Ce, Eu and Lu are shown in Figure 2 and 


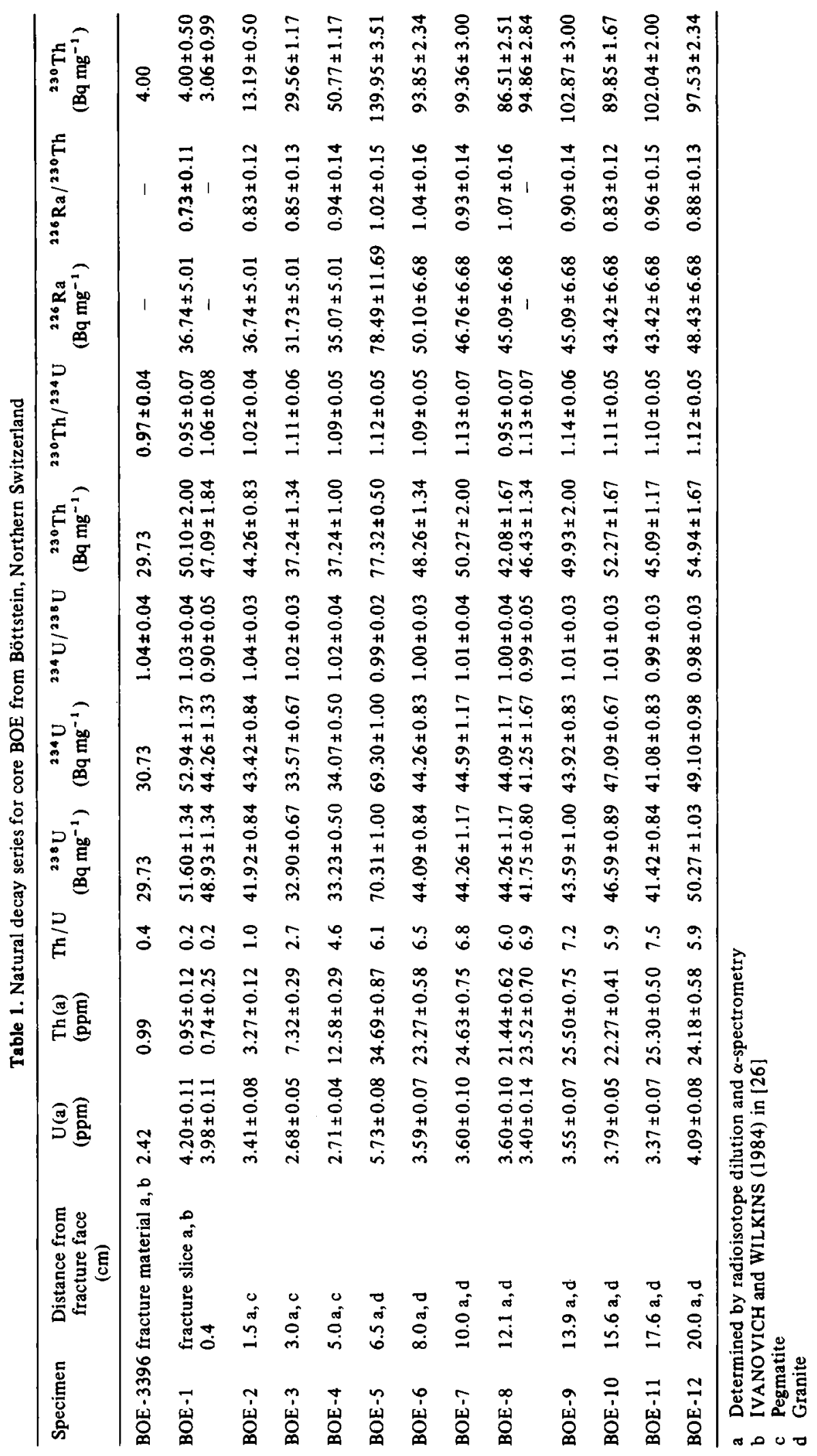


Table 2. INAA results for core BOE from Böttstein, northern Switzerland (All concentrations are in ppm unless otherwise stated.)

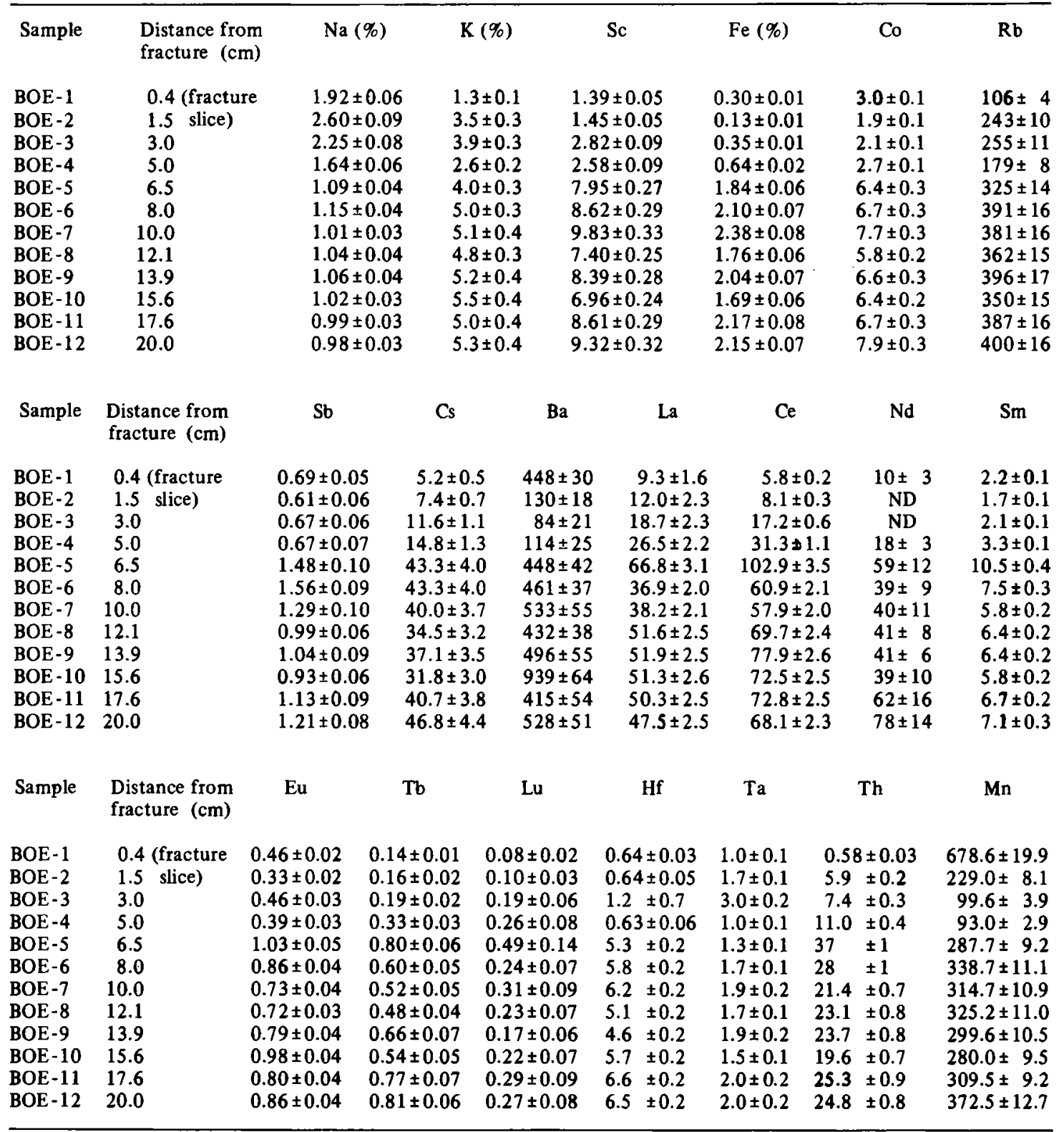

are tabulated in Table 2 along with $\mathrm{Na}, \mathrm{K}, \mathrm{Sc}, \mathbf{R b}, \mathrm{Sb}, \mathrm{Ba}$, Hf, Ta, Th (by INAA) and the REE's Nd, Sm and Tb. The presence of the pegmatite-granite contact, as defined by the mineralogy of the core (increased mafic content etc.), by the increase in $\mathrm{Na}$ and $\mathrm{Ta}$ levels and by the associated increase in $\mathbf{K}$ and $\mathbf{R b}$ concentrations on moving from pegmatite into granite, is marked on both Figures 1 and 2 , by a hatched line.

$\mathrm{U}$ and $\mathrm{Th}$ are relatively invariant in the granite until the pegmatite contact where there is a jump in the $U$ content to the core maximum with an associated increase in the Th content. Both $U$ and Th then fall sharply in the pegmatite with Th decreasing continuously to the fracture while $U$ increases once more in the last two centimetres before dropping again in the fracture material.
The $U$ and Th contents of the fracture material are $2.4 \mathrm{ppm}$ and $0.90 \mathrm{ppm}$ respectively $(\mathrm{Th} / \mathrm{U}$ ratio $=0.4)$ while in the associated pegmatite the $U$ concentration ranges from 2.68 to $4.20 \mathrm{ppm}$ whereas the Th displays a much larger concentration range of 0.74 to $12.58 \mathrm{ppm}$ (mean Th/U ratio of 0.7 ). There are no other data for unfractured pegmatites in this area but aplites from the same drillcore have similar Th concentrations ( 7.81 to $16.62 \mathrm{ppm}$ ) and high $U$ concentrations (10.88 to 29.88 ppm) with a mean Th/U ratio of 0.95 [1]. This indicates that, as well as the clear loss of $U$ from the pegmatite, there has also been a loss of Th at some stage.

In the granite adjacent to the pegmatite, the $U$ content ranges from 3.37 to $5.73 \mathrm{ppm}$ and the Th content ranges from 21.44 to $34.69 \mathrm{ppm}$ (mean $\mathrm{Th} / \mathrm{U}$ ratio of 

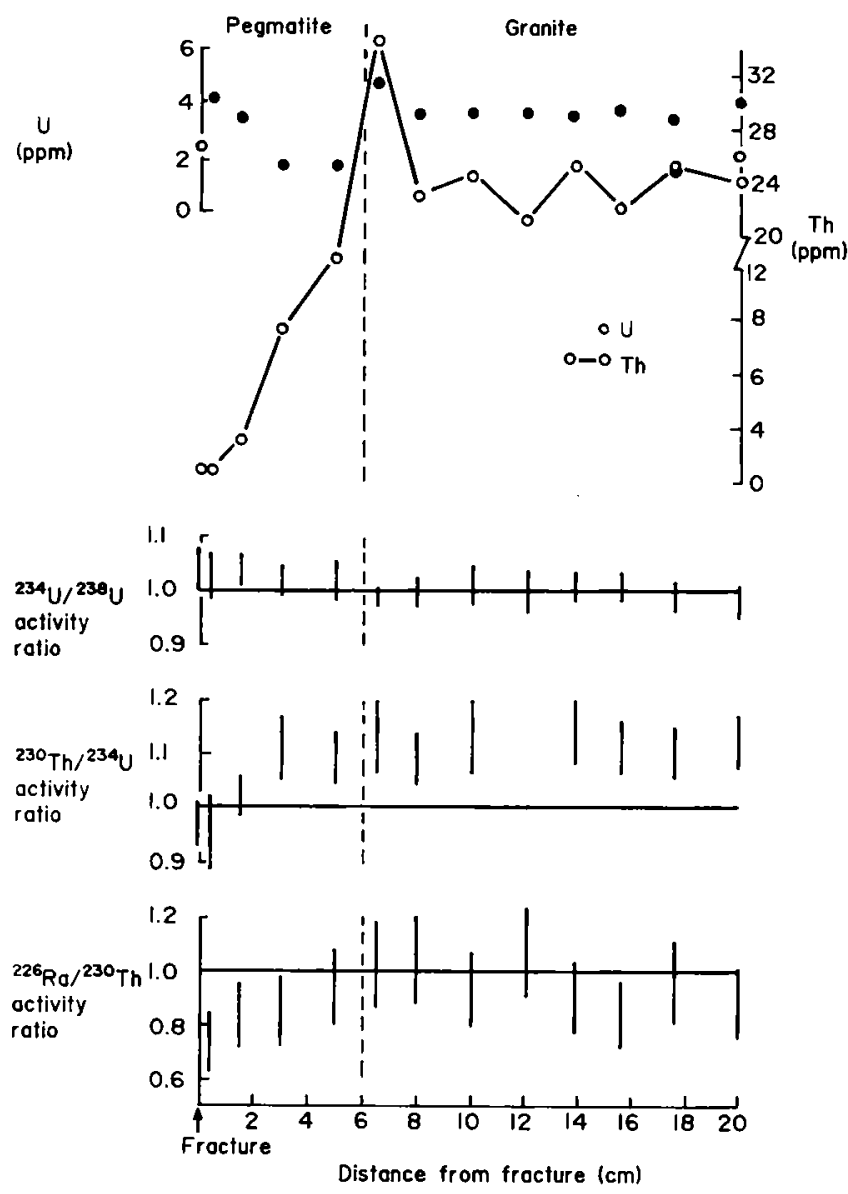

Fig. 1. Natural decay series results for core BOE.

6.5). Fresh, unaltered granite from elsewhere in the drillcore displays a range in $U$ concentrations of 8.6 to 10.4 ppm and a range in Th concentrations 19.8 to $29.3 \mathrm{ppm}$ (mean Th/U ratio of 2.65) [9] indicating a significant depletion of $U$ in the study granite with Th seemingly immobile.

It has been reported [1] that the core mineralogy indicates that the granite has been subject to a hydrothermal event, presumably in association with the intrusion of the adjacent pegmatite. The alteration extends for at least $8 \mathrm{~cm}$ into the granite from the pegmatite contact with strong argillisation producing illite, smectite, calcite (in $\mathrm{K}$-feldspar) and dispersed Fe-oxhydroxides as secondary phases. It is likely that this event remobilised and leached at least part of the original $U$ in the granite (cf. $[10,11])$. There has also been some remobilisation and reconcentration of $U$ and $T h$ at the pegmatitegranite contact reflecting the high temperatures experienced in this zone (pegmatite fluid temperatures have been estimated at $400-600^{\circ} \mathrm{C}$ [12]); the contact is also characterized by an increase in mafic mineral content.

Apart from the slight rise in the ${ }^{234} \mathrm{U} /{ }^{238} \mathrm{U}$ ratio in the pegmatite section of core BOE (Figure 1), the pattern effectively indicates secular equilibrium throughout. The re is, however, significant deviation from unity in the ${ }^{230} \mathrm{Th} /{ }^{234} \mathrm{U}$ activity ratio with average ratios of 1.1 to 1.5 throughout most of the core. There is a rapid drop, within
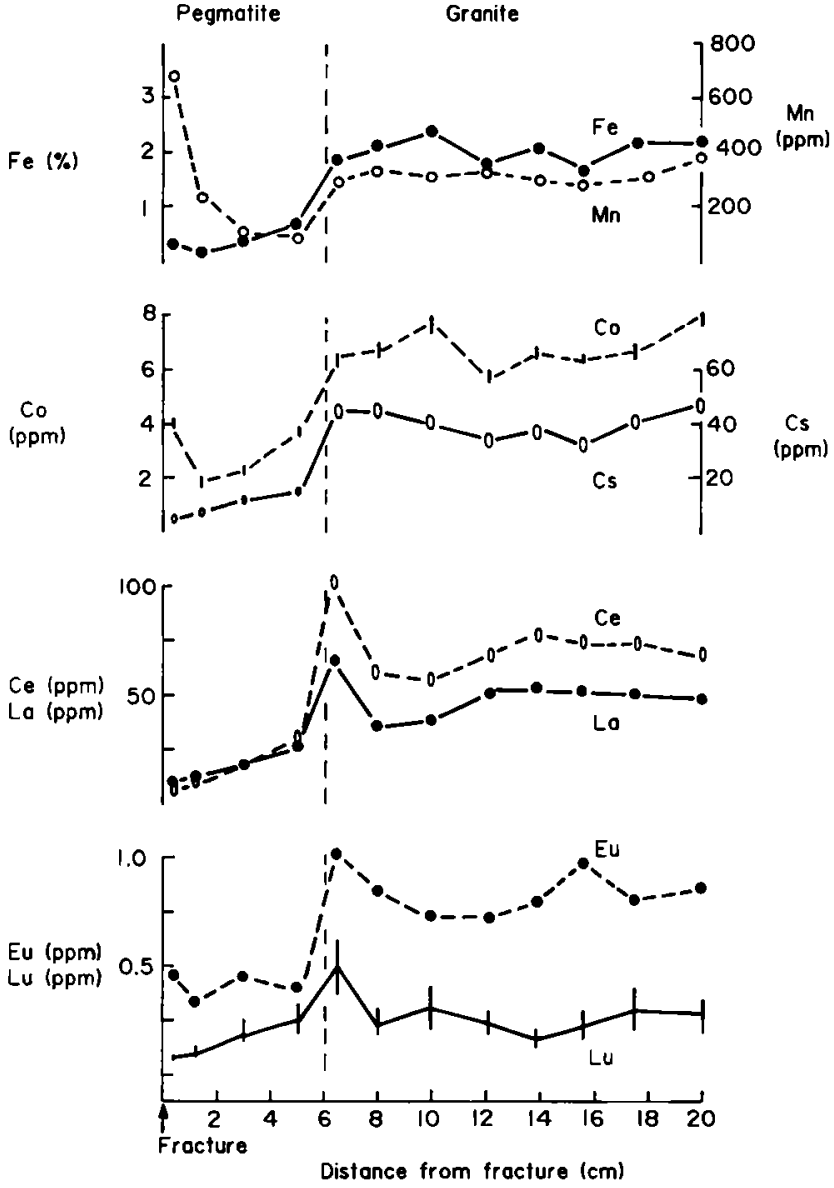

Fig. 2. Fe, Mn, Co, Cs and the REE's Ce, La, Eu, and $\mathrm{Lu}$ in core BOE.

the pegmatite, over the last $3 \mathrm{~cm}$ to the fracture with the fracture slice and fracture material both slightly less than unity. A similar pattern occurs in the distribution of the ${ }^{226} \mathrm{Ra} /{ }^{230} \mathrm{Th}$ activity ratios although in this case the activity ratios are unity throughout most of the drillcore and fall over the last few centimetres approaching the fracture to a minimum of 0.73 in the fracture slice (Figure 1, Table 1).

The REE's generally mimic the distribution of Th although there is also a systematic decrease in the REE levels from $14 \mathrm{~cm}$ to $8 \mathrm{~cm}$ where there is then a sharp increase in concentrations associated with the pegmatitegranite contact. Similar redistribution of REE as a product of hydrothermal alteration have been reported for a range of environments [13-17] although other low temperature mechanisms could also produce such changes [18].

$\mathrm{Fe}, \mathrm{Mn}, \mathrm{Co}, \mathrm{Cs}$ (Figure 2), Ba, Sc, Sb and Hf (Table 2) display similar patterns with little variation throughout the granite followed by a sharp decrease across the pegmatite-granite contact. Unlike U, Th and REE there is no comparable reconcentration of any of these elements (nor K, Na, Rb and Ta: Table 2) at the contact and this presumably reflects the differing mineral associations of these two groups. Unfortunately fission track analyses are not available for these samples but $U$ and Th (and the REE) were probably associated with zircon and apatite 
originally [1] although the abundance of mafic minerals at the pegmatite-granite contact suggests an association with these constituents now.

\section{Discussion}

Drillcore BOE provides evidence of several stages of mobilisation of a range of elements including the actinide analogues $U, T h$ and the REE.

The natural decay series radionuclides are especially useful in the study of element migration in the granite since the range in the half-lives of the daughter nuclides means that the degree of equilibration between the parent-daughter pairs can be used to provide information about the time scale of various rock-water interactions. Considering only the granite to begin with, if it is assumed that the Th is immobile under most natural water conditions (see later for qualifications) the ${ }^{230} \mathrm{Th} /{ }^{234} \mathrm{U}$ activity ratios of 1.1 clearly indicate a loss of ${ }^{234} \mathrm{U}$ from the rock. However, as the ${ }^{234} \mathrm{U} /{ }^{238} \mathrm{U}$ activity ratios are unity, the removal of $U$, over the length of the drillcore, was non-fractionated with ${ }^{238} \mathrm{U}$ equally as mobile as the ${ }^{234} \mathrm{U}$. From the overall nature of the isotopic compositions it can be infered that the $U$ migration was initiated some time in the last 300000 years or so either as a single event or as a continuous process which is still on-going.

Mathematical interpretation of the data [19] suggests that the U migration, from rock to solution, has in fact been a continuous process over this period with a probability of removal of some $10^{-6}$ per atom of $U$ per year over a distance of at least $20 \mathrm{~cm}$ from the fracture. If this is the case, then previous repository safety assessment calculations which assume only limited matrix transport (although they would certainly be conservative), may have to be re-assessed. Admittedly this granite has undergone a hydrothermal alteration (possibly associated with the Permian (?) pegmatite emplacement) and the argillisation has probably initiated conditions which have allowed easy access of geologically recent ground waters to U-bearing phases. Nevertheless, the significance of the continuous $\mathrm{U}$ migration throughout the length of this drillcore to safety assessment models, indicating as it does the presence of a large volume of the rock matrix which is accessible to actinides migrating in the granite groundwater system of a radioactive waste repository, should not be underestimated.

Within the pegmatitic part of the core $(0$ to $6 \mathrm{~cm})$ there is clearly a change in the distribution of the natural decay series radionuclides. With decreasing distance from the fracture there is an increase in the ${ }^{234} \mathrm{U} /{ }^{238} \mathrm{U}$ activity ratios and a concommitant decrease in the ${ }^{230} \mathrm{Th} /{ }^{234} \mathrm{U}$ and ${ }^{226} \mathrm{Ra} /{ }^{230} \mathrm{Th}$ activity ratios. This implies an input of ${ }^{234} \mathrm{U}$ to the rock, possibly by solution to solid ${ }^{234} \mathrm{U}$ $\alpha$-recoil gain $[20,21]$ or more likely by a sorption mechanism $[22,23]$, which would simultaneously produce the observed ${ }^{234} \mathrm{U} /{ }^{238} \mathrm{U}$ and ${ }^{230} \mathrm{Th} /{ }^{234} \mathrm{U}$ activity ratios.

This event has obviously occurred recently enough to prevent re equilibration of the ${ }^{230} \mathrm{Th}$ with its parent
${ }^{234} \mathrm{U}$ so maintaining the disequilibrium. However, it is important to note that, at the same time as ${ }^{234} \mathrm{U}$ uptake is occurring, the re is an apparent loss of ${ }^{226} \mathrm{Ra}$ from the rock with the ${ }^{226} \mathrm{Ra} /{ }^{230} \mathrm{Th}$ activity ratios (Figure 1) dropping below unity. Examination of the data in Table 1 shows no evidence of ${ }^{226} \mathrm{Ra}$ loss, with the level constant around $35 \mathrm{~Bq} \mathrm{mg}^{-1}$ throughout the pegmatite. Rather there is an increase in the ${ }^{230} \mathrm{Th}$ content of the pegmatite the nearer the fracture indicating an associated solution to rock transfer of ${ }^{230} \mathrm{Th}$ produced in a ${ }^{234} \mathrm{U}$ rich solution. Again the mechanism is unclear although a solubility control seems most likely in this case [24]. If this is so then it places further constraints on the time of the pegmatite associated $U$ migration event since the ${ }^{226} \mathrm{Ra}$ would re. equilibrate with its parent ${ }^{230} \mathrm{Th}$ in less than 8000 years or so.

Also of interest for radioactive waste safety assessment evaluation is the behaviour of the radionuclides in the vicinity of the fracture zone. Why is this zone different?

Along with the uptake of ${ }^{234} \mathrm{U}$ (and ${ }^{230} \mathrm{Th}$ ) in this zone there appears to have been a large removal of all elements analysed (apart from $\mathrm{Na}$ and $\mathrm{Ta}$ ) with increasing removal as the fissure is approached. It is tempting to suggest that the compositional changes observed across the pegmatite are associated with the presence of the fracture (see Figure 1), however, a more reasonable explanation is that they are simply a reflection of the mineralogical zoning previously described in some pegmatites [12]. This is believed to be produced by the repeated passage of fluids, of varying composition, along a particular route during pegmatitic crystallisation [25]. Although, from the examination of hand specimens and thin sections, there is no obvious mineralogical zonation in core BOE this does not preclude a chemical zonation similar to that observed in the layered ultramafic intrusions of the Skaergaard, Skye, Rhum and Bushveld complexes where such cryptic layering is well documented (see [26] for a review). If the migrating fluids dissolve previously formed minerals faster than they deposit new ones, open cavities may result; this appears the likely explanation for the coincidence of the present fracture with the observed chemical zoning.

Undoubtledly the timing and nature of each fluid flow was complex but, on a simplistic level, we may assume that the present element distribution patterns relate to a later, if not the latest, event overprinting previous signatures. Thus we might say that, assuming flow was along the present fracture, the fluid was low in Th, REE, $\mathrm{K}, \mathrm{Sc}, \mathrm{Rb}, \mathrm{Sb}, \mathrm{Cs}$ and $\mathrm{Hf}$ and high in $\mathrm{Fe}, \mathrm{Mn}, \mathrm{C}$ and $\mathrm{Ba}$ (Figures 1 and 2 and Table 2). Certainly ${ }^{34} \mathrm{~S}$ values from a baryte in vein material from a depth of $618.72 \mathrm{~m}$ imply a hydrothermal origin [27].

A chondrite-normalized diagram (Figure 3) provides further information on the hydrothermal fluid. Note that the samples from the granite proper have not been plotted as they all lie very close to sample BOE-5 $(6.5 \mathrm{~cm})$. Clearly there is in creasing removal of all REE with decreasing 


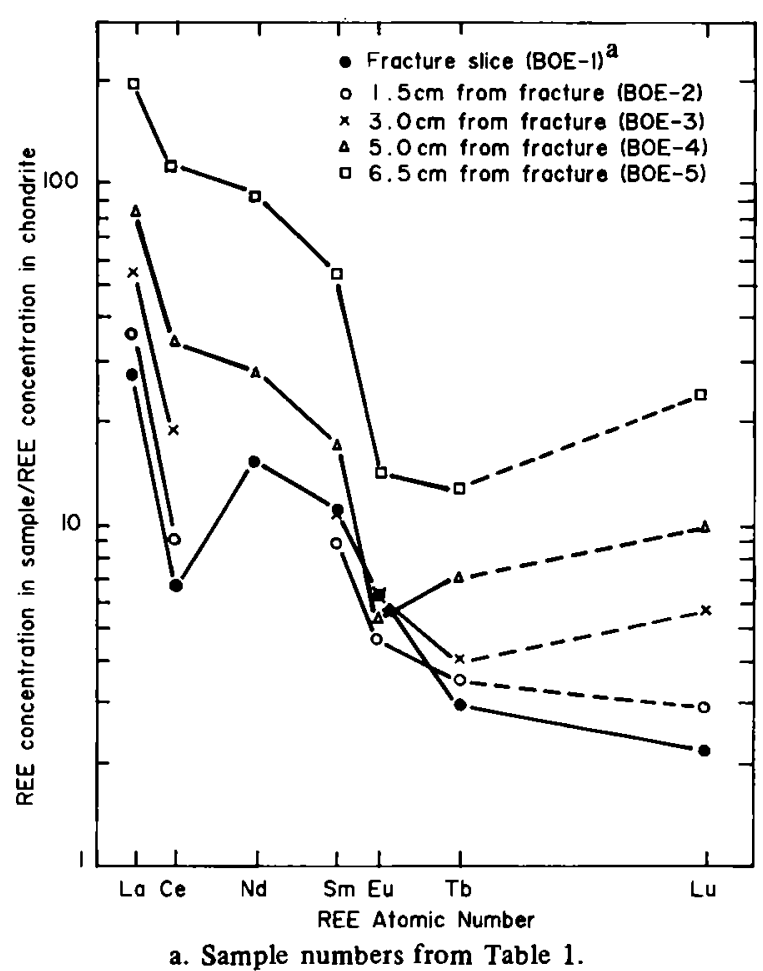

Fig. 3. Chondrite normalized plot of the REE distribution with distance from the fracture.

distance from the fracture but also note that there is a preferential loss of three of the REE's, Ce, Eu and Tb. This may be a reflection of the original fluid composition (see discussions in 28 ) or alternatively may be a reflection of the redox control of these elements. Under oxic conditions the three REE are stable as $\mathrm{Ce}^{4+}, \mathrm{Eu}^{3+}$ and $\mathrm{Tb}^{4+}$. but will enter solution under anoxic conditions in the $\mathrm{Ce}^{3+}, \mathrm{Eu}^{3+}$ and $\mathrm{Tb}^{3+}$ state [29-31]. We suggest then that the $\mathrm{Ce}, \mathrm{Eu}$ and $\mathrm{Tb}$ anomalies observed in the pegmatite indicate that the hydrothermal fluid was anoxic so removing these three REE selectively from what was originally a non-REE depleted pegmatite (note also that the anomalies slowly "straighten out" with distance from the fracture indicating a reduction in the penetration of the fluid into the pegmatite). According to previous work on the REE in hydrothermal systems (see the discussion in 32 and the references there in) this REE mobility implies relatively high water/rock ratios. A similar mechanism may be invoked to describe the profiles of $\mathrm{Fe}, \mathrm{Mn}$ and $\mathrm{Co}$ in the pegmatite with supply of these elements (in the reduced form) from the hydrothermal fluid to the rock occurring contemporaneously with the selective REE removal. Fe and $\mathrm{Mn}$, for example, could be accommodated in the (schorl) tourmaline which is randomly scattered throughout the pegmatite.

Such a process cannot, however, explain the uptake of $U$ (and ${ }^{230} \mathrm{Th}$ ) by the pegmatite because $U$ is insoluble in the reduced state. Of course, if hydrothermal fluids were particularly enriched in $\mathrm{F}^{-}$or $\mathrm{Cl}^{-}$then $\mathrm{U}$ could be soluble even in reducing conditions [33]. However, the lack of preferential removal or addition of light compared with heavy REE in the pegmatite suggests that there was not an unusually high concentration of either of these anions in the fluids [34]. This, and the time limit placed on the $\mathrm{U}$ and $\mathrm{Th}$ deposition (discussed above), indicate supply from more recent, more oxidizing circulating fluids, be they from the granite or the fracture (present day groundwaters from this depth interval [27] have ${ }^{234} \mathrm{U} /{ }^{238} \mathrm{U}$ and ${ }^{230} \mathrm{Th} /{ }^{234} \mathrm{U}$ activity ratios of 2.85 and 0.01 respectively). While the time constraints indicate that the $\mathrm{U}$ deposition was a much later event than the locally identified $U$ ore mineralisation [9] it is, of course, possible that the deposited $U$ represents material remobilized from these ores. The similarity in form of the $\mathrm{U}$ and ${ }^{230} \mathrm{Th}$ profiles to those of $\mathrm{Fe}, \mathrm{Mn}$ and $\mathrm{Co}$ does, however, suggest that the hydrothermal alteration of the pegmatite is exerting some control on the $\mathrm{U}$ and Th deposition. Perhaps the previous hydrothermal events have produced sites in the pegmatite which are suitable for the retention of migrating radionuclides with the gradation in degree of uptake with distance from the fracture a direct effect of the degree of alteration of the pegmatite indicated earlier by the REE profiles (Figure 3).

\section{Conclusions}

a) The emplacement of the pegmatite in the granite has induced peripheral re-concentration of the actinide analogues $U$, Th and the REE.

b) Subsequent alteration of the pegmatite has leached some elements (REE) and added others ( $\mathrm{Fe}, \mathrm{Mn}$ ) from what is presumed to have been an anoxic fluid.

c) There has been continuous migration of $U$, from the granite, over the last few hundred thousand years. This un-fractionated mobilisation of $U$ may have been induced in part by hydrothermal alteration of the granite and the altered rock has thus become accessible to geologically more recent U-leaching fluids. This data suggests that safety assessment models may have to be altered to take into account the possible effects of large volumes of rock being accessible to fluids migrating in a repository.

d) More recent U-enriched fluids have deposited ${ }^{234} \mathrm{U}$ (and ${ }^{230} \mathrm{Th}$ ) in the altered zone of the pegmatite. The fact that this zone is peripheral to the fracture cannot be taken as evidence that the $U$ was supplied by fluids circulating in the fracture system. The U-supply is as likely to have been from the granite or even to re. present remobilized U-ore.

\section{Acknowledgements}

This project was funded by NAGRA whose support is grate fully acknowledged. A.B.M and R.D.S would like to thank JOHN SMELLIE (SKB) with whom they carried out the initial work on this core. Thanks also to ANDREAS GAUTSCHI (NAGRA) for constructive discussion on this report. W.R.A. would like to thank T.M. WILLIAMS and R.M. MALCOLMSON (both SURRC), J. MEYER (Min.Pet. Uni. Bern) and B. KONING (PSI). 


\section{References}

1. SMELlie, J. A. T., MACKENZJE, A. B., SCOTT, R. D.: An analogue validation study of natural radionuclide migration in crystalline rocks using $\mathrm{U}$-series disequilibrium studies. Chem. Geol. 55, 233 (1986).

2. LAMOTHE, P. J., FRIES, T. L., CONSUL, J. C.: Evaluation of a Microwave Oven System for the Dissolution of Geological Samples. Anal. Chem. 58, 188 (1986).

3. ALEXANDER, W. R., WILLIAMS, T. M.: Microwave oven dissolution of granites and marine sediments: implications for natural decay series analy ses. (Submitted to J. Radioanal., Nucl. Chem. Lett.), (1988).

4. BACON, M. P., ROSHOLT, J. N.: Accumulation rates of ${ }^{230} \mathrm{Th},{ }^{231} \mathrm{~Pa}$ and some transition metals in the Bermuda Rise. Geochim. Cosmochim. Acta 46, 651 (1982).

5. MACKENZIE, A. B., SCOTT, R. D., MCKINLEY, I. G., WEST, J. M.: A study of long term $\left(10^{3}-10^{4}\right.$ y) elemental migration in saturated clays and sediments. IGS, London Rep. No. FLPU 83-6 48pp (1983).

6. MACKENZIE, A. B., BOWDEN, P., KINNAIRD, J. A.: Combined neutron activation and particle track analysis of element distributions in a rock slice of mineralized granite. J. Radioanal. Chem. 82, 341 (1984).

7. HARRIS, I.: unpubl. SURRC Internal Report (1985).

8. NTB84-25. Erläuterung zur "Geologischen Karte der Zentralen Nordschweiz, 1.1000000" NAGRA, Baden (1984).

9. Peters, TJ., MATTER, A., BLÄSI, H. R., GAUTSCHI, A.: Sond ierbohrung Böttstein Geologie. NTB85-02, NAGRA, Baden (1985).

10. BROOKINS, D. G.: Trace element studies of the Oklo natural reactor, Republic of Gabon. In: The significance of trace elements in solving petrogenic problems and controversies, ed. S. S. AUGUSTIT HIS, Theophrastus Publications, Athens 1983.

11. BROOKINS, D. G.: Natural analogues for radwaste disposal: Elemental migration in igneous contact zones. Chem. Geol. 55,337 (1986).

12. HATCH, F. H., WELLS, A. K., WELLS, M. K.: Textbook of Petrology, vol.,1: petrology of the igneous rocks. 13th ed., Thomas Murby and Co., London 1975.

13. CORLISS, J. B.: The origin of metal-bearing submarine hydrothermal solutions. J. Geophys. Res. 76, 8128 (1971).

14. N ESBITT, H. W.: Mobility and fractionation of rare earth elements during weathering of a granodiorite. Nature 279 , 206 (1979).

15. Alderton, D. H. M., PEARCE, J. A., POTTS, P. J.: REE mobility during granite alteration: evidence from south-west England. Earth Planet. Sci. Lett. 49, 149 (1980).

16. ClAUER, N., STILlE, P., BONNOT-COURTOIS, C., MOR RE, W. S.: Nd-Sr isotopic and REE constraints on the genesis of hydrothermal manganese crusts in the Galapagos. Nature 311, 743 (1984).

17. PAlACIOS, C. M., HEIN, U. F., DULSKI, P.: Behaviour of REE's during hydrothermal alteration at the Buena
Esperanza copper-silver deposit, northern Chile. Earth Planet. Sci. Lett. 80, 208 (1986).

18. HUMPHERIS, S. E.: The mobility of REE's in the earth's crust. In: Vol. 2 of Developments in Geochemistry, Elsevier, Amsterdam, ed. P. HENDERSON 1984, p. 317.

19. ALEXANDER, W. R., MACKENZIE, A. B., SCOTT, R. D., MCKINLEY, I. G., FALLICK, A. E.: Natural analogue studies using the natural decay series radionuclides: I. the influence of water-bearing fractures on radionuclide immobilisation in crystalline rock repository. II. uranium remobilisation in the Grimsel Felslabor. NAGRA, Technical Report NTB87 - 08 (1988).

20. FLEISCHER, R. L., RAABE, O. G.: Recoiling alphaemitting nuclei. Mechanisms for uranium series disequilibrium. Geochim. Cosmochim. Acta 42, 973 (1978).

21. ROSHOLT, J. N.: Isotopic composition of $U$ and $T h$ in crystalline rocks. J. Geophys. Res. 88, 7315 (1983).

22. HSI, C-K. D., LANGMUIR, D.: Adsorption of uranyl onto ferric oxyhydroxides: Application of the surface complexation site binding model. Geochim. Cosmochim. Acta 49, 1931 (1985)

23. BARNEY, G. S., LANE, D. L., ALLEN, C. C., JONES, T. E.: Sorption and desorption reactions of radionuclides with a crushed basalt-bentonite packing material. Rockwell Hanford Report No. RHO-BW-SA - 416 P (1985).

24. LANG MUIR, D., HERMAN, J. S.: The mobility of thorium in natural waters at low temperatures. Geochim. Cosmochim. Acta 44, 1753 (1980).

25. QUIREKe, T., KREMERS, H.: Pegmatite crystallization. Am. Mineral. 28, 571 (1943).

26. COX, K. G., BELL, J. D., PANKHURST, R. J.: The interpretation of igneous rocks. George Allen and Unwin, London 1979.

27. PEARSON, F. J. (ea.): Isotope investigations of the hydrogeochemical programme in northern Switzerland. NAGRA NTB88-01 (1988).

28. HENDERSON, P. (ed.): Rare earth element geochemistry (vol 21). Elsevier, Amsterdam 1984.

29. VICKER Y, R. C.: Chemistry of the Lanthanons. Butterworths Sci. Publ. London 1953, p. 269.

30. ELDERFIE LD, H., GREAVES, J. M.: The REE in seawater. Nature 296, 214 (1982).

31. ELDERFIE LD, H., SHOLKO VIT Z, E. R.: REE in pore waters of reducing nearshore sediments. Earth Planet. Sci. Lett. 82, 280 (1987).

32. VOKE, R. D., HANSON, G. N., GR UNENFELDER, M: Rare earth element mobility in the Roffna Gneiss, Switzerland. Contrib. Mineral. Petrol. 95, 145 (1987).

33. LANG MUIR, D.: Uranium solution-mineral equilibria at low temperatures with applications to sedimentary ore deposits. Geochim. Cosmochim. Acta 42, 547 (1978).

34. TAYLOR, R. P., FRYER, B. J.: REE geochemistry as an aid to interpreting hydrothermal ore deposits. In: Metallization associated with acid magmatism. Ed. A. M. EVANS, Wiley and sons, London 1982. 